レーザーオリジナル 1

脳外科用炭酸ガスレーザーメス実用機開発の研究:III

\title{
滝 澤 利 明*
}

(1978年6月10日 受理)

Studies on the Development of a Practical Model of the Carbon

Dioxide Laser Surgical Unit for Neurosurgery (Part III)

Toshiaki TAKIZAWA*

(Received June 10, 1978)

\section{2 その他の臨床領域への応用 \\ 5.2 .1 皮虚科}

色素性母斑及び，単純性血管腫 (portwine mark）に対しては色依存性を利用してアルゴ ンレーザーやルビーレーザーが従来用いられて

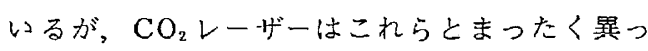
た作用機序で有効に利用できることを知った。 病変の面積が広い場合は全身麻酔下に，また， 狭い場合は局所麻酔下に50W程度の出力で直径 数mmの defocused beamで照射するとまず表皮 の一部が瞬間的に層状に剝離して風船のように 膨隆する。これは組織液が蒸気になって爆発的 に膨張するからである。beamを速いスピード でscandせてから, 生理的食塩水を侵したガー ゼで一ふきするとこの剥離した層は容易にとり 除かれる。この際, 病変が浅いcaseではこの 一回のscanで色素沈着も血管腫も消失する。そ して出血も，浸出もみられず露出した面は平滑 であり，焼きこげもみられない。病変が深い場 合は，更にもう一回照射する。2回目からの照 射は直径を少しせばめてやや焦げ目がつく程度 の方がよい。これを同じく生理食塩水に浸した
ガーゼでふきとる。この操作を病変が消失する まで重ねる。手術は大変迅速に行易に行われる。 現在, 術後経過をfollow up中であるがこれま でのところ経過は良好である。この術式を著者 はlaser peeling と呼んでいるが, laser peeling直後は周辺の皮齘に比して，白すぎるが， 10日目には健常の皮膚の色調が戻って来はじめ る。peelingによる術直後の浅い陥山は3日目 に周辺と同じ高さに戻る。現在までのところ, scarやケロイドを残した症例はないが今後 follow upする必要がある。またケロイドの治 療にも優れた成績をあげている。皮膚癌の除去 などにもよい適応である。皮膚科手術用にも出 力は大きい方が効率がよい。defocused beam の直径を大きくできるからである。

\section{2 .2 婦人科}

婦人科領域では現在のところ子宮膣部びらん cervical erosionの治療に適用し，良い結果を 得ている。子㗬胵部びらんの治療法としては現 在 cryosurgeryが一般に行われているが帯下 がきわめて多く，患者の言葉を借りるならば 「水道の上うに出る」と音う。多い時は1日に

* 東京大学医学部脳神経外科, 中央鉄道病院脑神経外科

* Department of Nerosugery, Faculty of Medicine, University of Tokyo.

* Department of Neurosurgery, Central Hospital of Japanese National Railways. 
$100 \mathrm{mI} ら 200 \mathrm{ml}$ に達し，パットの交換など患 者にとってわずらわしい。しかし， $\mathrm{CO}_{2} レ$ レ゙ 一で移行帯の円柱上皮を十分気化にすると術後, 带下も出血もほとんどない。そしてまたこの方 法は，電気焼灼より優れている。

\section{2 .3 外科}

痔瘦の根治手術は便利である。瘦孔にゾンデ を通し、これを目標にして皮虞, 皮下組織瘦孔 と一気に $\mathrm{CO}_{2}$ レーザーで切開し瘦孔を肉芽や細 菌と共に高温で気化消滅してしまう（Fig. 50)。 そのあと一時的に縫合してしまうことが可能で ある。手術は10分以内で終了する。従来の方法 では，組織の欠損が大きいが $\mathrm{CO}_{2} レ$ レ゙ーでは 最少限ですむ。

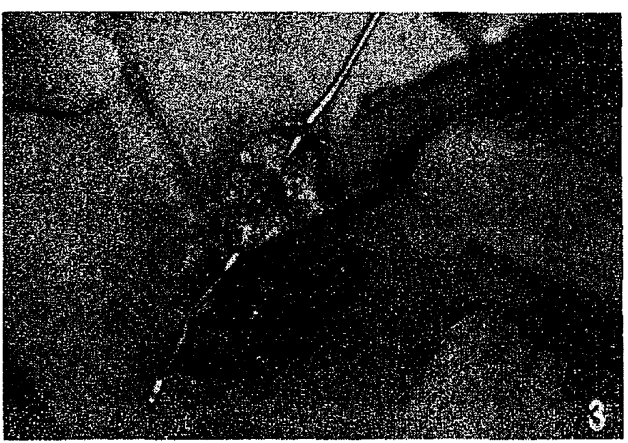

Fig. 50 Laser surgery of the hemorrhoidal fistula. The blunt probe is inserted into the fistula to indicate the target of vaporization.

その他, 肝臓手術, 脾臟摘出術等ではレーザ 一照射に先立って一過性に血管を遮断すると出 血が少ないことがわかっている。胃切除術も試 みられたが、これは従来の鋼メスの方が軽便で あり，外科医はその必要を認めない。

以上の他に，耳鼻咽喉科の手術（声帯ポリ一 プ等)に有用であることは報告されているが， 著者らには現在のところ自然例がないので割愛 する。耳鬾咽喉科頗域ではJako ${ }^{71}$ や三橋 ${ }^{81}$ す ぐれた事績をあげている。 $\mathrm{CO}_{2} レ$ レ゙ーは，今 後, ここにに述べなかった臨床領域でも新しい 適応が発昌され, laser surgeryの新しいtechniqueが開発されるであろうと思われる。

\section{6. 安全性について}

\section{1 使用上の安全性}

実用機の必要条件の一つに安全性の確保が容 易で且つ，確実でなければならないという点が ある。 $\mathrm{CO}_{2}$ レーザーの場合は眼球の保護とその 他の組織の保護と言う二点についてレーザーメ スを扱う医師, 看護婦, 見学者側と患者の双方 の保護を慮せねばならない。

6.1 .1 眼球の防護

6.1.1.1 $\mathrm{CO}_{2}$ レーザー

幸い, 波長 $10.6 \mu$ の $\mathrm{CO}_{2}$ レーザーはガラスを 透過しないので，メガネをかけているものはそ れでよいし，そうでない者は，素通しのメがネ をかければよい。色付のメガネの必要はないの で手術野の色調を損わずにすむ。ゴーグルは不 便で実際問題として手術には使えない。第一に ガラスが㬡りやすい。第二に側方の視野を防げ る。通常の型のメガネで十分である(Fig. 51)。

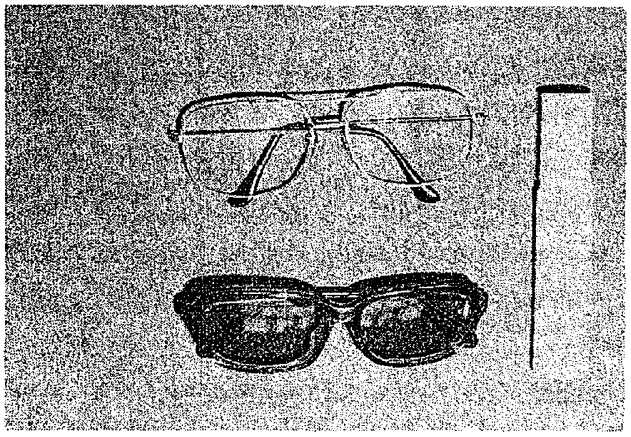

Fig. 51 The spectacles with the plain glasses which the author wears during the laser surgery for the protection of the eyes. surface-active agent (surfactant) is necessary to prevent the lenses from collecting moisture (right side). No spectacles are needed when the surgeons look into the operating microscope.

著者らはこの点を確認するために，手術室の照 明をすべて消し, 手術野の金属器具（吸引管,

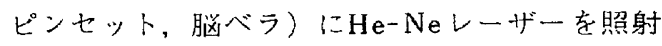
し，術者のメガネのレンズに厚紙を貼って眼球 が十分に反射光から防護されているか否か, 写 
真で確認した（Fig. 52）。その結果, Fig. 53の

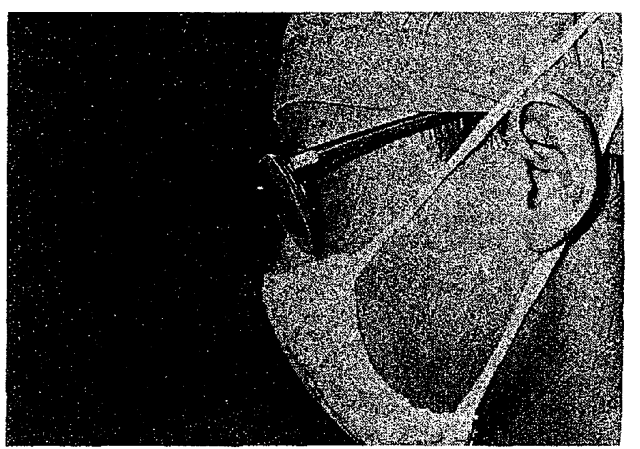

Fig. 52 Spectacles covered with the pieces of a thick paper were prepared for the ex. periment on the eye-protection.

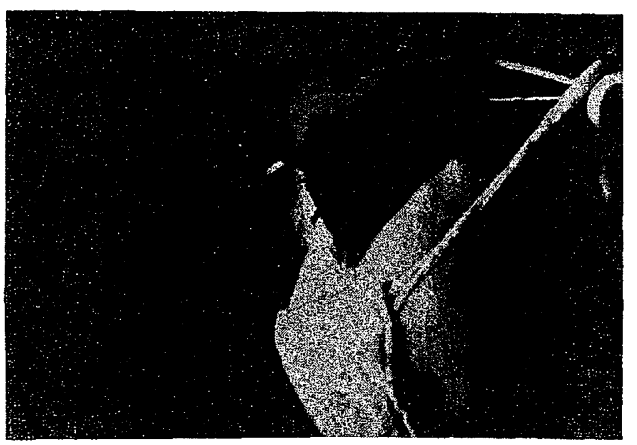

Fig. 53 The eyes are completely protected from the laser beam reflected by the surgical ilfstruments when the operator wears the ordinary glasses.

如く，眼球は完全に隍に入り，安全であること がわかる。メガネと顔の隙間から, 眼球にレー ザー光が入ることは実際にはない。成畫や文献 に見られるようにゴーグルやアスベストの手袋 をつけ，重いガウンを着て，しかも手術室の入 ロに「レーザー使用中につき立入禁止」のサイ ンを出さなくてはならぬとしたら，実際問題と して臨床手術は不可能であり，またその心要は ない。徉って今後，そのような安全基準を公的 に定める時には笑際にレーザーを使って手術を 行っている臨床医を中心にproject team をつ くって蚞討すべきであり，初期の頃の観念や基 準をそのまま借用するのは不要な足かせをはか せることになるので非現実的である。しかし， メガネをかけずに $\mathrm{CO}_{2} レ$ レ゙ーの一次光をのぞ
くことは絶対，避けねばならない。Fig. 54は家 兔の眼球の角膜に $\mathrm{CO}_{2}$ レーザーのfocused beam を出力 $30 W て ゙ ~ 0.5$ 秒間，照射した標本である。

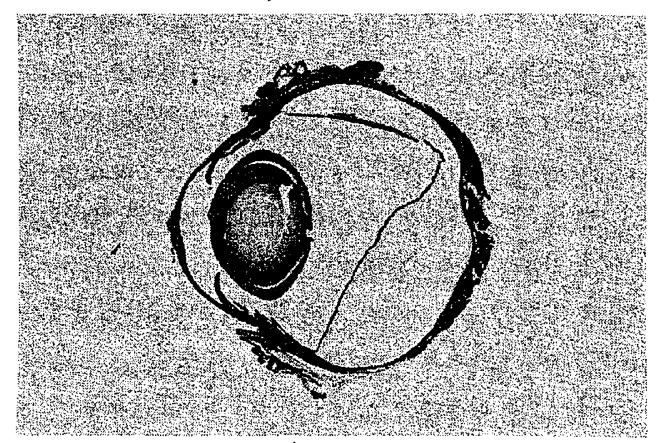

Fig. 54 Cornea is perforated in the instant of staring into the $\mathrm{CO}_{2}$ laser beam when it is not protected with glass.

角膜は瞬間的に穿孔し，前房水が流出する。水 晶体の前面のカプセルもわずかに影響が及ぶ。 現実にはこのような状況が手術中に生ずること はないが，もし生じたとしても，実際には一種 の逃避反射で顔を瞬間的にそむけるので障害が それ以上，深部に生ずることはない。 $\mathrm{CO}_{2} レ ー$ ザーは水に $100 \%$ 吸収されるので水晶体も，硝 子体も透過しないので, これらが気化消滅しな い限り，網膜には達し得ない。Fig.55は，家鬼

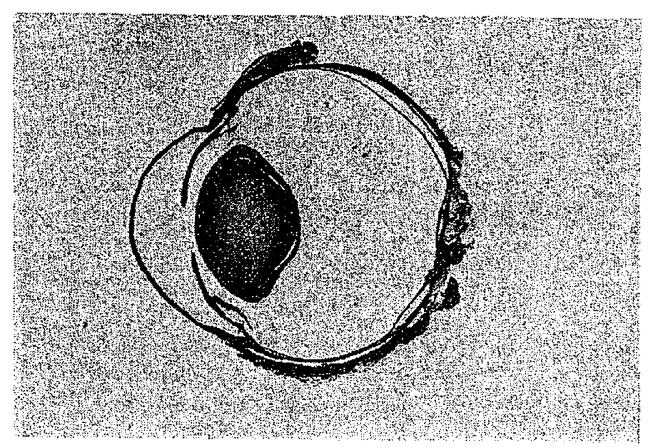

Fig. 55 The cornea remained intact after lasing when it was protected with a plain glass.

の眼球の削にスライドグラスを唯いてこれに $\mathrm{CO}_{2} レ$ ーザーの一次光を照射した堭合の標本で あるが角膜は笙全に保護されていることがわか る。同様の実験は反射光を用いても行われた。 金属慗の欶管べラを $45^{\circ}$ の角度に固定し，上方 
より出力 $20 \mathrm{~W} の \mathrm{CO}_{2}$ レーザーを照射して beam を水平に反射させ家兔の眼球に 0.5 秒ずつ 5 回 照射した。家兔は照射のたびにまばたきをする。 $\mathrm{CO}_{2}$ レーザーは不可視光であるが角膜がわずか ながら刺激されているのである。照射後，fluolescenceの溶液を点眼し 細隙灯顕微鏡で観察 すると角膜潰痬が緑色に染まってみえる。しか し，ガラスで覆った方の眼球はintactである。

$$
\text { 6.1.1.2 He-Neレーザー }
$$

我々の $\mathrm{CO}_{2} レ$ レ゙ーメスは 3 号機 MODEL MEL-442 “TAKYTOM-77”よりガイド光と して He-Neレーザーを内臓している。従って

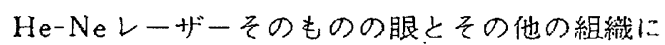
対する安全性をも実験して確認する必要がある。 “TAKYTOM 77”に内臟されている $\mathrm{He}-\mathrm{Ne}$ レーザーは低出力で $2 \mathrm{~mW}$ 程度であり、これが 途中で減衰され handpieceの出口では $1.2 \mathrm{~mW}$ 以下になっている。著者らはSpectra-Physics 社製の定 出力 $1.5 \mathrm{~mW}$ の $\mathrm{He}-\mathrm{Ne}$ レーザーを用 い黑色家鬼の眼球を一次光で直接 1 回60秒ずつ 週 3 回, 6ケ月間照射し, 眼底カメラで, 週 1 回ずつ観察したが，角膜，水晶体，硝子体等の 透明体はもちろんのこと網膜にもなんらの変化 を認めなかった。（Fig. 56)ガラスを眼前にお

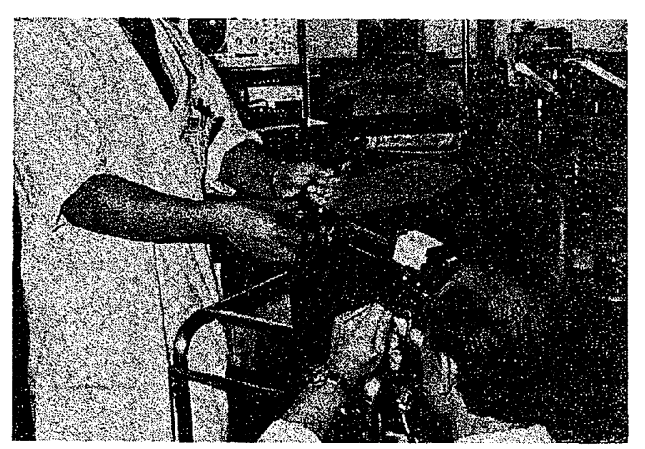

Fig. 56 Fundoscopy of a black rabbit after a long-termed exposure to $\mathrm{He}-\mathrm{Ne}$ laser. 30 diopter convex lens was attached to the fundus-camere (Kowa type RC-11).

いた実験も実地の手術に準じて行われたがもち ろん何らの異常を認めなかった。白色家鬼の網 膜は色素に之しく，とトの眼球の代用にならな いので有色家兔（茶，在，黒色）が用いられた。
$\mathrm{CO}_{2}$ レーザーの場合と同様の方法で $\mathrm{He}-\mathrm{Ne} レ$ 一ザーの反射光の実験も行われたが，結果は予 期どおり異常を認めなかった。

$\mathrm{He}-\mathrm{Ne} レ$ ーザーは波長6328Aで赤色光であり， 角膜, 前房水, 水晶体, 硝子体等の透明体には 吸収されず透過して網膜色素層に吸収される。 上述の如く，ガイド光に用いるような低出力で は網膜にはなんらの变化もないが, Kohtiao9

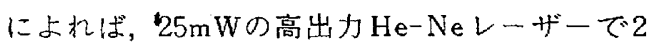
2. 5秒照射すると網膜に変化が来るという。著 者らは国鉄新幹線のトロリ一線摩耗を検出記録 する装置に内臟される高出力 $\mathrm{He}$ - Neレーザーを 黒色家兔の眼球に照射する機会を得たのでK。 Kohtiaoの実験の追試 ${ }^{10)}$ を行った（Fig. 57, 58）。

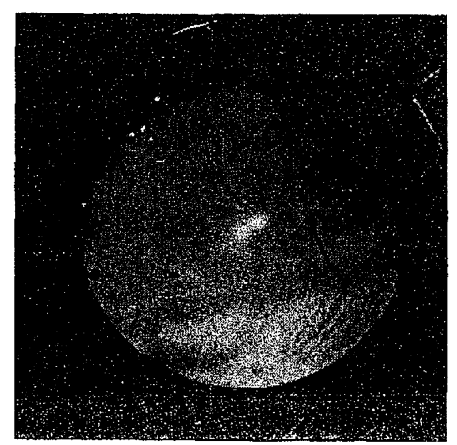

Fig. 57 The lesion produced on the retina adjacent to the papilla of a black rabbit after irradiation of $\mathrm{He}-\mathrm{Ne}$ laser with an output power of $26.5 \mathrm{~mW}$ and an exposure time of $3 \mathrm{sec}($ arrow). But similar lesion was produced with an exposure time of 1 sec.

出力 $26.5 \mathrm{~mW}$ では 1 秒間の照射でも網膜は損傷 された，しかし透明体には何らの変化も認めら れなかった。眼底カメラで follow upしたよこ ろ,この網膜の急性所見は4 週間で消褪した。

6.1 .2 その他の組織

$6.1 .2 .1 \mathrm{CO}_{2}$ レーザー

その他の組織の保護は朔述のように生理的食 塩水その他ともかく水を含んだ綿やガーゼで覆 えば完全に達せられる。通常，手術においては手 術野以外は全部滅菌布で覆ってしまうので問題 はない。䛈まってこれらの布類に照射されると 布が一部焦げるだけですむ。ゴム手垡も一次光 


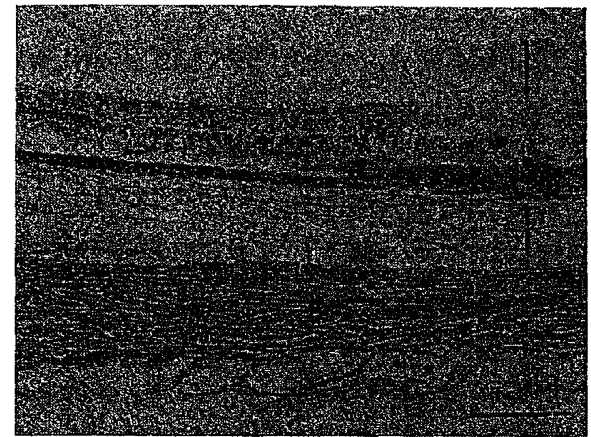

Fig. 58 Necrosis and edema produced on the retina of a black rabbit after irradiation of $\mathrm{He}-\mathrm{Ne}$ laser with an output power of $26.5 \mathrm{~mW}$ (power density: $5 \mathrm{~W} / \mathrm{cm}^{2}$ ). The lasing was performed with scanning beam and the rabbit was sacrificed 24 hours after irradiation. The arrows show the lesion. Hematoxylin-Eosine staining.

では孔があくし，反射光では多少の熱感を感ず る程度であるがこのようなことは過去 9 年閒に $2 \sim 3$ 回みられた程度である。反射光は遠くは なれた点ではpower densityがきわめて小さい ひでnegligibleである。実際，過去 9 年間，術 者や助手や看護婦に障害はみられていない。

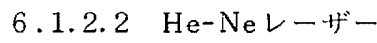

He-Neレーザーは網膜以外の生体組織には実 害がないので問題にならない。ガイド光に用い る程度の低出力ではもちろんであるが，たとえ $25 \mathrm{~mW}$ 程度の大出力でも皮㯺に直接, 照射して もなんらの变化もみられない。実際著者は前記 の笑験の折に自分の前腕の芚膚に，25 $\mathrm{mW}$ の He$\mathrm{Ne}$ レーザーを30秒照射してみたが熱感すら感 じなかった。”をの後も皮䖉になんらの变化も生 じていない。家鬼の皮虑に出力 $25 \mathrm{~mW}$ で 5 分間 照射してもなんらの変化もみとめられなかった。 網膜の細胞の方が皮荿の細胞よりも $\mathrm{He}-\mathrm{Ne} レ$ 一ザーに対してはるかに闌值が低いことと眼の 球のレンズで網膜_上に集光されて power density が20倍も高くなること, 及び皮膚は白色で He ーNeレーザーの赤色光をある程度反射するが網 膜色素層は黑色でこれを吸収するための相違で あろう。また家兔の網膜の方がヒトの網膜より 域値が低いと言われるから家兔で確諗された安
全性はとトに適用されても誤りでないと考えら れる。

\section{2 装置全体の安全性}

レーザー及びレーザーシステムの安全基準に 関しての公的機関より公表されたものとしては, 現在のところ，米国の ANSI (American National Standard Institute, Inc.) のレー ザーの安全使用方法に関するANS (American National Standard ANSI Z 136.1-1973) " が最も権威あるものである。我が国ではまだ公 的な基準がないが，日本電子機械工業会のレー ザー技術委員会 ${ }^{12)}$ がANSを中心に検討をすす めている。今後，国産のレーザーシステムを国 外に輸出する場合はこのANSを基盤にして， 米国のBRH (The Bureau of Radiological Health, the U.S Department of Health, Education and Welfare)が1973年 3 月に立案 公表し，同年12月10日，Federal Registerに 修正案として公告, 1974年9月4日にproposed rulemakingとして再公布したレーザー製品の 施行基準 Performance Standard for Laser Products ${ }^{131}$ （39 FR 32094）を十分, 考虑し ておく必要がある。ANSでは0.25秒以上連続 して作動するレーザーは連続波レーザーとみな されている。そしてレーザーの危険分類をclass $\mathrm{I}$ 一Vまで 5 段階に分類しているが，著者らの $\mathrm{CO}_{2}$ レーザーメス MODEL MEL-442

“TAKAYTOM-77”はclass VVに属する。 class N W直視はもとより, 拡散面からの反射 光が眼や皮膚にあたることも危険な高出カレー ザーで管理と医学的監視が必要なものである。 ANSでは0.5W以上の出力を有する連統波レ一 ザーはclass IVに属する。

著者らの $\mathrm{CO}_{2} レ$ ザーメスの安全装置として は下記のものがある。

1. ガイド光

ガイド光として $\mathrm{He}$ - Neレーザー(可視光線) を使用している。炭酸ガスレーザービーム(赤

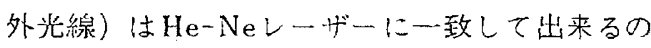
で，照射位置をHe-Neレーザーで確認してから 
炭酸ガスレーザーを出すことにより，照射位置 をまちがえるという事故を防ぐことができる。 2.ビームシャッター (DHEW/BRH Radi. ation Performance Standards, 21CFR Sub-chapter Jの1040・10の規格に従う。) Laser beamを遮断する装置でhandswitch もしくは foot switchをONにした時だけ， laser beamが通常できるようになっている。又， そのビームシャッターが閉じている時に，ビー ムシャッターを利用してレーザ一の出力を連続 的にモ二ターすることができ，そのため出力の 設定が容易にでき，ハンドピース先端から出る レーザーを安全にコントロールできるので，予 定外の出力がでるというような事故を防ぐこと ができる。

3.手元スイッチ及びキースイッチ（DHEW）

BRH Radiation Performance Standards 21CFR Sub-chapter Jの1040・10の規格に 従う。)

レーザー動作のために必要な高圧スイッチ (H.Vスイッチ) が術者の手元にあるので，術 中にレーザーを使わない間だけ術者はそのスイ ッチを手心で切っておくことができ，それより 術者以外の者がまちがってスイッチを踏んだ場 合でもレーザーが出ないようになっている。又, 主制御の出来るキースイッチがコントロール敞 についており，このキーをはずすとレーザー野 作ができないようになっている。

4.ブザー（同上の規格に從う。）

レーザーが handpiece 先端から出ている時ブ ザーが鹔るので，術者及び周囲の人にレーザー が出ていることを知らせることができ，非常に 安全である。

5. 真空スイッチ

レーザー管内の圧力がある一定値以下になら ないとレーザーが動作しないようになっている。 管内の圧力が50Torrになると真空スイッチが ONL，100TorrでOFFするようになっており， ガス压が高いことによるレーザー管内の異常放 電を防いでいる。

6。冷却油温度娭出スイッチ
レーザー管を冷却するための冷却油の温度が 十分に下がっていないとレーザー管が，非常に 高温になり誴動作の原因となるので，冷却油が ある一定温度以下の時にレーザーが動作するよ うになっている。

7. 油圧スイッチ

冷却油がきちんと流れているかどうかを唡知 し，冷却油が流れていない時にはレーザーが動 作しないようになっている。

8. 冷却にはオイルを使用

電気を絶縁するオイルを使用しているので万 一漏れるようなことがあっても電気的に安全で 南る。

9.ネオントランスを使用し，交流放篦で動作 ネオントランスを川い，交流放電でレ一ザー を動作させているので，万一，ヘッド内部の高 圧部に触れて感電したとしても，ネオントラン スに $20 \mathrm{~mA}$ 以上流れないため，電気ショックが 非常に少なく，事故を最少限におさえることが できる。

10. 漏電ブレーカー内蔵

電源内部に漏電ブレーカーが内藏されている ので，何らかの事情で30 $\mathrm{mA}$ 月上漏電した時に ブレーカーが働き，電源が切れるようになって いる。

\section{1. ブレーキ}

本体を固定するためのブレーキがあり，手術 中，看護媂などが誤って本体に触れたとしても， 簡単には動かないようになっており，術者の譟 操作を防ぐことがでさる。

12. 電磁ロック

術中，レーザーを使わない間だけ一睦的にへ ッド部及びストローク部を固定することが術者 の手元ででき，handpiece等が不潔なものに接 触することを防ぐことができる。

13. 滅菌フィルター

handpieceの先端から瀷の流入を防ぐ空気が 出ている。その空気滅菌フィルターを通って きたものであるから非常に清潔である。

14. ガス隇菌が可能

ストローク部及びhandpieceは取り外しが容 
易に行え，ガス滅菌が可能であるから，清潔な 手術が行える。

15. dural protector

硬膜を切開する際, 硬膜直下のクモ膜及び脳 表を保護するために, handpieceの先端に装着 する attachmentである（Fig. 20)。

\section{7. 考察}

上述の如く $\mathrm{CO}_{2}$ レーザーメスは組織の切離の みならず，凝固止血，組織の無血的気化消滅が 可能で，その機能は多岐にわたり他の波長のレ 一ザ一の機能が比較的限られているのに較べる と適応が広い。しかし，凝固能のみをとり出し て比較するとYAG laserの方がすぐれている と考えられる。YAG laserは波長1.06

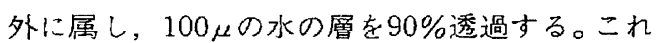
に反して、, $\mathrm{CO}_{2} レ$ レ゙ーは $100 \mu$ の厚さの水に $99.9 \%$ 吸収され，0.1\%透過するにすぎない。 従って組織の熱凝固属は $\mathrm{CO}_{2}$ レ一ザーより厚く, それに比例して凝固止血能力が高まる。しかし， それに反比例して切離能は $\mathrm{CO}_{2}$ レーザーにはる かに劣る ${ }^{14 \% 15}$ 血管網が発達して高度に出血性 の腫瘍を除去する際に， $\mathrm{CO}_{2} レ$ ザーだけでは controlできず，電気メスを併用せざるを得ぬ 場合があるが，もし，YAG laserを併用できれ ば，まずYAGレーザーで腫瘍を凝固し，次い で $\mathrm{CO}_{2}$ レーザーで vaporizeすればすべての出 血は完全に予防できると思われる。しかし，そ の場合，問題になるのは価格と電源であろう。 Y A Gレーザーの効率は低く, 一定の出力を得 るのに大電源を要する。従って, 3 相, 200Vの コンセントを手術室に設営せねばならない。ま た，きわめて高価な装置を 2 台備えることは一 般には無理であろう。

$\mathrm{CO}_{2}$ レーザーメスの将来の夢は，10.6 長を透過するfiber opticsの開発である。こ礼 によりYAGレーザー並のflexibilityが得られ， 外科医の不満が大巾に解消寸ると思われるから である。すでに米軍ではある程度の成功をみた と言う情報があり $\mathrm{TaBr}$ 等，今後諓が国でも研 究が進められるものと期待される。
$\mathrm{CO}_{2}$ レーザー用のfiber opticsが完成されな い限り,メスの軽便さになじんだ外科医達は関 節方式の surgical armに大きな不満を抱きつ づけるであろうが，その外科医達も認めている 点は肝臓の手術等, 実質臓器の外科である。 Gonzalez ${ }^{161}$ らは犬の肝臓の切離縁からの出血

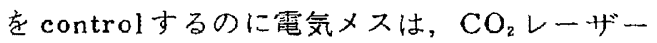
メスの 5 倍の出血量を記録し，止血に要する時 闑は $\mathrm{CO}_{2} レ$ レ゙ーメスの14倍であったと記載し ている。しかし一方，Filder ${ }^{171}$ らは同じく犬 の肝臓を切離する際の出血量は電気メスに比較

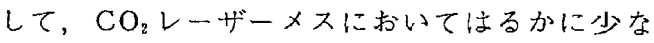
いが，止血に要する時間には有意の差はなかっ たとしている。 Hall ${ }^{18)}$ は肝臓の切離に際して, hepatic vesselsをあらがじめ結架しておけば 出血舅は電気メスで40\%, $\mathrm{CO}_{2}$ レーザーメスで 85\%も減少させることができると言っている。 これらの研究者の報告にみられる差は結局，同 じ装置を使用していないこととlaser surgery

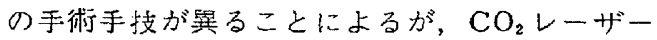
メスが止血能で電気メスに優つている点は共通 している。本邦では綿貫 ${ }^{19}$ らがとトの肝臓手 術にModel MEL-442を用いて満足すべき結果 を得ている。

S. Stellar ${ }^{61}$ は $\mathrm{CO}_{2} レ$ レ゙ーの作用が“gen. tle”であると述べているが，この“gentleness” は脳外科手術にとって好ましい性翼である。お だやかに腫瘍組蟣が術者の意図するままに気化 消滅する有様を実際に一度でもみれば $\mathrm{CO}_{2} レ ー$ ザーを脳腫癔に適用することの妥当性は这外科 医なら誰でも認めるであろうと思われる。

事実，前述のStellar山初期の頃にこの良さ を認めた 1 人で基整的な実験をすませた後，臨 椺応朋も行っているが使用した装置が実験機で あったため、臨床応用は発展しなかったものと 思える。1973年に東宗に於いて第 5 回国際脳神 経外科学会が開催された折に，著者らは Dr. Stellarの来訪を受けたが，その頃我々の装置 は丁度，1号機から2号機に移行军る時代であ った。Stellar沙その頃すでに，著者らの2 号 機に相当する程度の装疽を用いていたが，4年 
経過した1977年サンパウロにて開催された第 6 回国際脳神経外科学会で再会した時にはすでに 著者らのチームの方が脳外科用塞用機の時代に 入っており，米国での目立った発歷はみられな かった。同学会で著者らはそれまでの実験と臨 床手術を16mmカーフィルムにおさめて上映し たが，かなりの反響があった。゚ーつにはlaser surgeryをはじめてみた聴衾が多かったのと日 本の工業製品に対する国際的評洒があったため であろうと思われる。我々の他には才ーストリ アのGraz大学脑神経外科のHeppner ${ }^{21}$ とAscher がイスラエル製の Sharplan 791 を用いた $16 \mathrm{~mm}$ 映画を上映し, Stellar も American Optical 製り装置を用いた初期の頃の映画を追加した。 また，同学会においてはじめて「这外科におけ るlaser surgery」がmorning seminar のテ ーマの一つにとり上げられ，Stellarを座長に Heppner, Ascher, 神川代著者を講師として 開催されたが、これはレーザーが世界の脳外科 医達の関心を意くにいたったことを淑しいる。 現在脳外科用 $\mathrm{CO}_{2}$ レーザーメスを開発している のは著者らのチームだけであるが，Ascher221 らはイスラエルの Laser Industries Ltd. 製 の沉用 $\mathrm{CO}_{2} レ$ ーザーメスSharplan 791を㮸外 科用に改良し attachments や micro-manipulatorの改良を含めて Microlaser Sharplan 733 と命名している。従って現在脳外科用専用 機は日本とオーストリアにあるわけである。

Sharplanの開発者の一人であるテルアビブ 大算の Prof. Koplan ${ }^{23)}$ が来日した折に著者の 質問に答えて「Sharplan $791 の$ 開発に着手し たのは1972年であり，自分は形成外科医なので American Optical製の装置を川いて下腿潰瘍 や3度火傷等の手術をはじめたが不便なので自 分自身で新しいタイプを䦌発することにした。 そして現在のモデルに满足している。」と答え ている。形成外科領域の laser surgeryは体表 の手術であり, 出力も中程度ですみ, 脳外科の ように高出力から低出力まで極端な出力調整を 要求されたり，手術用顕微鏡下の細かい要求が ないのでスタートが遅くとも実用域に達するの
が比較的早かったのであるうと思われる。イス ラエル製の Sharplanは世界の主としてユダヤ 系の病院に購入され，1975年11月テルアビブで The First International Symposium of Laser Surgery ${ }^{24 !}$ がひらかれている第 2 回 目は1977年10月米国のDallasでひらかれたが, 第 3 回目は1979年 9 月, オーストリアのGraz で開催される予定である。

目を国内に転ずると神川251 らが主としてア ルゴンレーザーを用いた仕事を発表しているが 著者らはむしろ $\mathrm{CO}_{2} レ$ レ゙ーメスの非色依存性 に着目して1969年に研究に着手してから 5 年後 の1974年，第33回日本脳神経外科学会を皮切り に第34回，第35回，第36回，同学会，1976年12 月，東工大 $\mathrm{ME}$ 講演会，1977年第一汇医用レー ザ一研究会にて発表し，また論文 ${ }^{101261.271 .281}$ 発 表もして来たが特に1977年 4 月の第16|山1ME学: 会にては学術展示も行い実物を作動させた。こ れらの努力の結果, 国内の脳神経外科医の中に も次第に $\mathrm{CO}_{2} レ$ ザーの存在，またはmeritを 知る人々も子え，実際に手術を依頼されること も多くなってきた。いずれ需要に応じて装置を

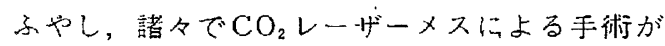

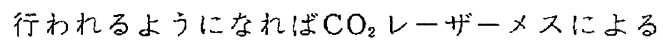
国内のsymposiumや研究会がひらかれるように なるであろうし，波膚科や婦人科を含めて健康 保険の点数も定められるようになる日が来るで あろうことは C T や手術用顕微鏡の使用に保険 点数が定められた経過をみても時間の問題と思

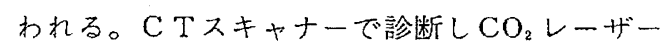
メスで手術するスタイルが rautinlになる日は 近いであろう。

\section{8. 要約}

著者らは1969年, 脳外科用炭酸ガスレーザー メス実用機開発の研究に着手し, 試作 1 号機か らスタートして実腅モデルの3 号機に至った。 この実用機 Medilaser-S Model MEL-442 “TAKYTOM-77”を開発する過程では光顕及 び電顕による型態学的検索とサーモグラフ，マ イクロサーミスター, 非接触性赤外線温度計に 
よる温度実験が行われ， $\mathrm{CO}_{2}$ レーザーの生物学 的作用は型態学的にも熱的にも極めて限局的で あることが確認された。ついでこの装置を用い て脳外科, 外科, 皮膚科, 婦人科の laser surgeryが行われたが，その臨床成績はいずれも画 期的であった。

脳外科領域においては現在のところ脳腫瘳が そのもっともよい適応で, 従来の modalitiesで は不可能であったような出血性腫瘍の無血的除 去や硬くて除去困難な線維性腫瘍のnon-contact removal by vaporizationが行われた。 $\mathrm{CO}_{2} レ$ ーザーメスの安全性に関しては使用上の注意と 安全装置について記載した。

\section{9. 謝辞}

著者が脳外科用炭酸ガスレーザーメス実用機 開発の研究を志ざしたのは1969年であったが, 以来 9 年間, 実に多くの人々の献身的な協力と 並々ならぬ御厚意により今日まがりなりにも実 用機として現実に日の目をみることができ，感 謝に耐えない。このprojectは本来多額の資金 と各種のエキスパートが必要であり，とうてい 一人個人のなしうるところではない。本研究の 立案, 発想, 方向づけは著者個人の創意によっ てなされたが，実施の段階になるとこれらの人 々の協力なしでは一歩も進めないのである。本 来ならば一人一人全員の抬名前をあげて謝辞を 述べるべきであるが紙数の都合でそれができず 申し訳けなく思う次第である。大勢の協力者の 中で特筆すべき方々だけを述べさせていただく と筆頭は中央鉄道病院脳神経外科主任医長の松 本正久博士である。松本博士は臨床手術の他, 実験動物の購入，動物実験の際のモ二ター等諸 機器の操作から動物の屍体の南と仕末に至るま でまた高価な装置から記録用フィルムに至る までの購入，折衝を当局と行い，更に16mmカラ 一映画による手術記録を一手にひきうけ，樑夜 早朝に至るまでフィルムの編集を行うなど，休 日を返上して 9 年間惜しみなくバックアップし て下さり，その功縊は計り知れない。本研究の 完成は同氏に負うところ多大であり，心から感
謝したい。次に同じく中央鉄道病院脳神経外科 医師山崎隆氏である。動物実験も臨床手術もす ベて山崎氏の助力で行われ，MEの medical sideは著者と松本氏と山崎氏の三人のグループ であった。永年にわたる同氏の献身的協力は松 本氏と並んでこの仕事に不可欠であった。さて E sideの筆頭は持田製薬株式会社々長持田信夫 氏である。持田氏は著者とは別個に $\mathrm{CO}_{2}$ レーザ 一メスの開発を考えておられ，実施に踏み切る 段階で著者らのグループと合流し，共同開発の 運びとなったのであるが，同氏の先兒の明と英 断と強い意志がなかったらこのプロジェクトは 日の目を見ずに終ったであろう。しかも後述の 優秀なレーザ一技師達を抜擢し有て上げ，今日 の成功をもたらした功績は偉大である。

さて実際に著者の構想を現実の装置に具現化 してくれたレーザー技師は, 持田製薬 $\mathrm{ME}$ ）東 郷隆志，竹内一政，田端光博の三氏である。こ の装置の細部は彼等自身の創意工夫により完成 されたのは言うまでもない。著者のみるところ， この三人の技師は現在我国で実際に $\mathrm{CO}_{2} レ$ 一゙ 一メスを手がけている人間としては第一人者で あると言っても過言でない。この三氏は永年に わたり，手洐や実験の際に早朝から深夜までス タンバイして装置の開発改良につとめたがその 努力の結晶がMODEL MEL-442である。この 三氏と前任者である酒井洋, 中根正昭の両氏に は試作 1 号機， 2 号機の時代にお世話になった。 持田製薬事業部部長, 木村宏朗氏,太田辰三デ イレクター, 故短上登喜吉常務の三氏には経理 面で永年にわたり苦労をおかけした。同社広告 部の諸氏には $16 \mathrm{~mm}$ 映画のナレーションの録音の 際お世話になった。光顕病理標本作成は中央鉄 道病院中央検查病理の宇佐美一彪氏に，また電 顕標本作成は同病理の早川欽哉医長に引きうけ ていただいた。細菌培䓹は同㮩查部の稲田次郎, 片山勝利氏に御協力いただいた。家兔の眼球を 用いた安全性の実験は中央鉄道病院眼科の諸氏 の協力があり，C-57 blackmouse の実験腫瘍 は国立癌七ンター脳神経外科部長 (現東京大学 脳神経外科助教授）高倉公朋氏の御厚意により 
入手し，継代した。

著者が1969年に本研究に着手した際，心よく

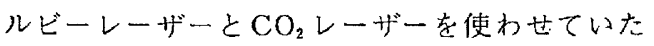
だいた東京大学医用電子研究施設長渥美和彦教 授と東京女子医大理論外科, 桜井靖久教授に心 より感謝する。なぜならそれが今日の実用機開 発につながったからである。ことに渥美教授に はその後永年にわたり，御指導御鞭達いただい て今日に至っている。また本論文を「レーザ一 研究」に揭載の労をとって下さった近畿大学理 工学部の久保宇市教授と「レーザー瑟談会」の 斉藤善久氏に感謝し，また御迷惑をおかけした おわびを述べたい。

おわりに本研究のスタートより, 指導教官と

して永年にわたり適切な助言とあはげましをい ただいた恩師, 東京大学脳神経外科, 佐野主闻 教授に心より感謝の意を表して稿を終る。

\section{参 考 文 献}

1) Cushing, H., Bovie, W. T.: Electro-surgery as an aid to the removel of intracranial tumors. Surg. Gynecol. Obstet. 47:751-784, 1928

2) Greenwood, J., Jr.: Two point coagulation. Am. J. Surg. 50: 267-270, 1940

3) Maiman, T.: Stimulated optical radiation in ruby masers. Nature. 187: 493-494, 1960

4) Javan, A., Bennet, W. B., Jr., Herriot, T. R.: Population inversion and continuous optical maser oscillation in a gas discharge containing a $\mathrm{He}-\mathrm{Ne}$ mixture. Phys. Rev. Lett. $6(3): 106-110,1961$

5 ) Patel, C. K. N.: High power carbon dioxide lasers. Scient. Am. 219:23-33, 1968

6 ) Stellar, S.: Experimental studies with the carbon dioxide laser as a neurosurgical instrument. Med. Biol. Eng. 8: 549-558, 1970

7 ) Jako, G. J.: Laser surgery of the vocal cords. An experimental study with carbon dioxide lasers on dogs. The Laryngoscope. 82:2204 -2216 , No. 12, 1972

$8)$ Mihashi, S., Jako, G. J., Incze, J., Strong, M. S., Vaughan, C. W.: Laser surgery in otolaryngology: Interaction of $\mathrm{CO}_{2}$ laser and soft tissue. Annals of the New York Academy of Sciences. 267:263-294, Third Conference on the Laser, 1976
9) Kohtiao, A., Resnick, I., Newton, J., Schwell, H.: Temperature rise and photocoagulation of rabbit retinas exposed to $\mathrm{CW}$ laser. Am. J. of Ophthalmology. 62: No. 3, 524-527, 1966

10）滝澤利明，山崎隆，松本正久，長南常男，宇佐美一 彪, 堀木健次, 牧野秀臣, 磯谷維辰, 塚田一也: 昼間用卜ロリ線摩耗測定装置に内藏せるへリウムネ オンレーザーの眼球及び皮膚に対する影響について 集電計測の研究 N 76-17：付録 $1-5,1977$

11) American National Standards Institute, Inc.: American National Standard for the Safe Use of Lasels. ANSI Z I36.1 - 1973: 9-59, 1973

12）社团法人日本電子機械工業会レーザー技術委員 会：レーザーの安全使用方法（ANSI基準Z 136.1 1973) 解説書, 1-37, 1974

13) Department of Health, Education, and Welfare-Food and Drug Administration: Federal Register Part 1l, Laser Products-Performance Standards. 40 : No. 148, 32252-32266, 1975

14) Karbe, E., Beck, R., Englisch, W., Königsmann, G., Kramer, H., Petersen, W. D.: Experimental Surgery with Neodymium, Holomium, $\mathrm{CO}$ and $\mathrm{CO}_{2}$ Lasers, Laser Surgery-Proceedings of the 1 st International Symposium on Laser Surgery, Israel, 5-6, November, 1975: 174-177, 1976, Jerusalem Academic Press

15) Grotelüschen, B., Reilmann, H., Bödecker, V., Buchholz, J.: A high power Nd-YAG-Laser ( $\mathrm{CW}$ and $\mathrm{Q}$-switch) as a cutting tool in experimental surgery. Laser Surgery: 167173, Jerusalem Academic Press, 1976

16) Gonzalez, R., Edlich, R. F., Bredemeier, H. C., Polanyi, T. G., Goodale, R. L., Wangenstein, O. H.: Rapid control of massive hepatic hemorrhage by laser radiation. Surg. Gy. necol. Obstet. 131(2):198-200, 1970

17) Fidler, J. P., Hoefer, R. W., Poianyi, T. G., Bredemeier, H. C., Siler, V.E., Altemeier, W. A.: Laser surgery in exsanginating liver injury. Ann. Surg. 181 (1): 74-80, 1975

18) Hall, R. R.: Haemostatic incision of the liver: Carbon dioxide laser compared with surgical diathermy. Br. J. Surg. 58: 538-540, 1971

19）綿貫喆：第 3 回 $\mathrm{CO}_{2}$ レーザーメス研究会、1978, personal communication

20) Takizawa, T., Yamazaki, T., Matsumoto, M. Mayanagi, Y., Amano, K., Sano, K., Atsumi, K., Togo, T., Takeuchi, K., Mochida, N.: Stu Studies on the development of the carbon dioxide laser surgical unit for practical use. (16mm Movie film, color) Sixth International Congress of Neurological Surgery, Sâo Paulo. Motion Pictures 1 V-335, 1977 
21) Heppner, F., Ascher, P.W.: The use of laser in neurosurgery (16mm Movje film). Motion Pictures $\mathrm{N}-335,1977$

22) Ascher, P. W.: Der $\mathrm{CO}_{2}$ Laser in der Neurochirugie. 1977, Verlag Fritz Molden

23) Kaplan, L., Ger, R., Sharon, U.: The carbon dioxide laser in plastic surgery. Brit. J. of Plastic Surg. 26: 359-362, 1973

24) Kaplan, I.: LASER SURGERY, Proceedings of of the 1 st International Symposium on LASER SURGERY, Israel, 5-6, November, 1975 JERUSALEM ACADEMIC PRESS, Jerusalem, 1976
25) Kamikawa, K., Hayakawa, T., Ikeda, T., Kuroda, R., Murui, H., Ushio, Y.: Argon laser treatment of brain tumor sensitized with acridine orange. Medical J. of Osaka Univ. 26: No. $1-2,61-67,19 \dot{7} 5$

26) Takizawa, T.: Comparison between the Laser surgical unit and the Electrosurgical Unit. Neurologia medico-chirurgica. 17: Part 1 , $95-105,1977$

27）滝澤利明：炭酸ガスレーザーメス塞用機開発の現状 上将来医科器械学、第47巻第 9 号; 462-467, 1977

28）滰澤利明：脳腫演の Laser surgery. 神経研究の 進歩, 第22巻, 第 1 号; $101-110,1978$ 